\title{
A Zebrafish Model for Uremic Toxicity: Role of the Complement Pathway
}

\author{
Nathaniel Berman ${ }^{a}$ Melisa Lectura ${ }^{b}$ Joshua M. Thurman ${ }^{c}$ James Reinecke \\ Amanda C. Raff ${ }^{b}$ Michal L. Melamed ${ }^{b}$ Zhe Quan $^{b}$ Todd Evans $^{a}$ \\ Timothy W. Meyer ${ }^{\mathrm{e}}$ Thomas H. Hostetter ${ }^{f}$ \\ ${ }^{a}$ Weill Cornell Medical College, New York, N.Y., ${ }^{b}$ Albert Einstein College of Medicine, Bronx, N.Y., ' University \\ of Colorado School of Medicine, Aurora, Colo., ' University of Nebraska Medical Center, Omaha, Nebr., \\ e Stanford University School of Medicine and VA Medical Center, Palo Alto, Calif., and ${ }^{\mathrm{f} C a s e}$ Western Reserve \\ University School of Medicine, Cleveland, Ohio, USA
}

\section{Key Words}

End-stage renal disease - Zebrafish model · Uremic toxicity

\begin{abstract}
Many organic solutes accumulate in end-stage renal disease (ESRD) and some are poorly removed with urea-based prescriptions for hemodialysis. However, their toxicities have been difficult to assess. We have employed an animal model, the zebrafish embryo, to test the toxicity of uremic serum compared to control. Serum was obtained from stable ESRD patients predialysis or from normal subjects. Zebrafish embryos $24 \mathrm{~h}$ postfertilization were exposed to experimental media at a water:human serum ratio of 3:1. Those exposed to serum from uremic subjects had signifi-

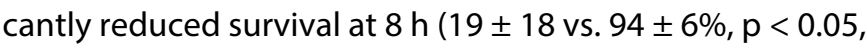
uremic serum vs. control, respectively). Embryos exposed to serum from ESRD subjects fractionated at $50 \mathrm{kDa}$ showed significantly greater toxicity with the larger molecular weight fraction ( $83 \pm 11$ vs. $7 \pm 17 \%$ survival, $p<0.05,<50$ vs. $>50 \mathrm{kDa}$, respectively). Heating serum abrogated its toxicity. EDTA, a potent inhibitor of complement by virtue of calcium chelation, reduced the toxicity of uremic serum compared to untreated uremic serum ( $96 \pm 5$ vs. $28 \pm 20 \%$
\end{abstract}

survival, $p<0.016$, chelated vs. nonchelated serum, respectively). Anti-factor $B$, a specific inhibitor of the alternative complement pathway, reduced the toxicity of uremic serum, compared to untreated uremic serum ( $98 \pm 6$ vs. $3 \pm$ $9 \%$ survival, $p<0.016$, anti-factor $B$ treated vs. nontreated, respectively). Uremic serum is thus more toxic to zebrafish embryos than normal serum. Furthermore, this toxicity is associated with a fraction of large size, is inactivated by heat, and is reduced by both specific and nonspecific inhibitors of complement activation. Together these data lend support to the hypothesis that at least some uremic toxicities may be mediated by complement.

Copyright $\odot 2013$ S. Karger AG, Basel

\section{Introduction}

Patients with end-stage renal disease (ESRD), including those receiving 'adequate' dialysis, are burdened with a complex array of metabolic derangements, clinical symptoms [1], and poor survival [2]. Compared to nor-

N. Berman and M. Lectura contributed equally to this work.

\section{KARGER}

E-Mail karger@karger.com

www.karger.com/bpu
(C) 2013 S. Karger AG, Basel

0253-5068/13/0354-0265\$38.00/0
T.H. Hostetter

University Hospitals Case Medical Center

Department of Medicine, Division of Nephrology and Hypertension

Room 8124 Lakeside Building, 11100 Euclid Ave, Cleveland, OH 44106 (USA)

E-Mail thomas.hostetter@uhhospitals.org 
mal people, a large number of solutes are elevated in the plasma of people with ESRD, even those receiving hemodialysis [3]. However, the relationship between these retained solutes and the residual uremic disabilities remains poorly understood. Among the solutes that have especially poor removal by hemodialysis are those that are protein bound, intracellular, or large. Therefore, they are especially elevated in dialysis patients [4]. Several epidemiologic studies have described a relationship between individual uremic solutes and mortality [5-7]. Research into the mechanisms of uremic toxicity has been limited in part by the lack of an animal model. Maintaining these animals on dialysis is technically fraught and has only rarely been attempted. Zebrafish have been used extensively to model environmental and pharmacological toxicity $[8,9]$. Zebrafish exhibit toxicity profiles similar to small mammals; toxic concentrations in ambient fishwater are consistently similar to toxic serum concentrations in experimental mammals [10]. Zebrafish produce hundreds of offspring per week, making them a relatively inexpensive and convenient model [11]. Experimental toxins can be added to fishwater, obviating complicated delivery systems.

In this study, a zebrafish model was employed to explore a mechanism of uremic toxicity.

\section{Methods}

Zebrafish mating pairs were maintained on a lighting schedule of $14 \mathrm{~h}$ light and $10 \mathrm{~h}$ darkness. Mating pairs were paired once weekly, and embryos were collected within $3 \mathrm{~h}$ of spawning. Embryos were maintained at $28.5^{\circ} \mathrm{C}$ in standard system water [11]. Embryos were manually dechorionated at the initiation of all experiments, with only the most robust normal and apparently healthy embryos used. Nine to 11 embryos at $24 \mathrm{~h}$ postfertilization of the same clutch were transferred into each well of a 6-well plate. Experimental medium was premixed and added to each well, then diluted with three parts fishwater to one part medium. Fishwater is reverse osmosis-treated distilled water with $60 \mathrm{mg}$ of Instant Ocean Sea Salt added per liter. During toxicity experiments, embryos were observed hourly for survival, defined as presence of a heartbeat, for $8 \mathrm{~h}$. This time interval was chosen from preliminary studies as the point at which approximately $90 \%$ of the embryos in the uremic solution had died. Results of experiments are expressed as percent survival at $8 \mathrm{~h}$, with the number of wells being the number of observations for an experiment.

Blood was obtained from stable maintenance hemodialysis patients before the initiation of treatment, or from volunteers without kidney disease, using standard separator tubes without anticoagulant. Samples were centrifuged for $15 \mathrm{~min}$ at 3,000 rpm. Serum was stored at $-30^{\circ} \mathrm{C}$ and then thawed in $40^{\circ} \mathrm{C}$ water for use. The study was approved by the institutional review board of Albert Einstein College of Medicine.

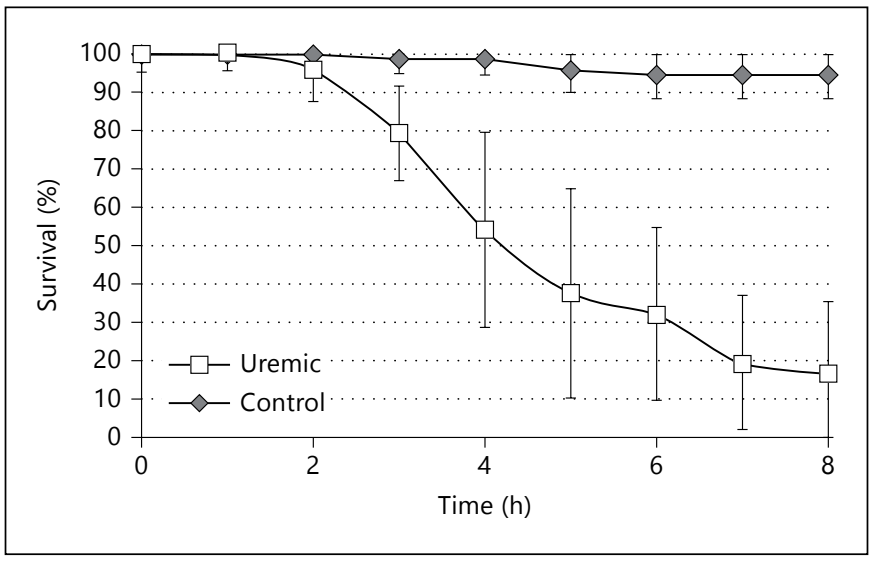

Fig. 1. A time-course plot of percent survival \pm SD in control vs. uremic serum for $8 \mathrm{~h}, \mathrm{n}=8$ ( $\mathrm{n}$ refers to the number of independent experimental observations, each evaluating the survival of approx. 10 embryos).

For separate solutes of large size, serum was centrifuged at $15,000 \mathrm{rpm}$ using Microcon centrifugal filters with a $50 \mathrm{kDa}$ membrane for 20 min (Millipore Corp, Bedford, Mass., USA). The ultrafiltered volume lost was replaced by saline in the initial serum sample. Heating experiments were performed by heating serum at $60^{\circ} \mathrm{C}$ for $30 \mathrm{~min}$. EDTA was added to serum at $10 \mathrm{mM}$ (before being diluted 3:1 in fishwater, as above). 500 ug of anti-factor B antibody mAb 1379 (stock $3.26 \mathrm{mg} / \mathrm{ml}$ ) and/or control murine IgG1 clone 171 (stock $23.5 \mathrm{mg} / \mathrm{ml}$ ) were used per $\mathrm{ml}$ of serum, then diluted 3:1 in fishwater as above.

\section{Statistics}

Statistical analysis was performed using unpaired two-tailed Student's t tests. Bonferroni correction was used for groups $n>2$. Results are reported as means $\pm \mathrm{SD}$.

\section{Results}

Zebrafish embryos exposed at $24 \mathrm{~h}$ postfertilization to uremic serum for $7 \mathrm{~h}$ had diminished survival, as compared to embryos similarly exposed to control serum ( $19 \pm 18$ vs. $94 \pm 6 \%, p<0.05$, uremic vs. control serum, respectively, with $n=8$; fig. 1). Fractionation of uremic serum demonstrated that toxicity was strongly associated with the $>50-\mathrm{kDa}$ component as opposed to the $<50-\mathrm{kDa}$ component, suggesting the toxic molecule(s) was either $>50 \mathrm{kDa}$ or protein bound ( $83 \pm 11$ vs. $7 \pm 17 \%, \mathrm{p}<0.05$, $<50 \mathrm{kDa}$ vs. $>50 \mathrm{kDa}$, respectively, with $\mathrm{n}=5$; table 1 ). Heating uremic serum abrogated its toxicity (100\% survival) as compared to unheated uremic serum $(32 \pm 25 \%$ survival) and normal serum ( $96 \pm 6 \% ; \mathrm{p}<0.016$ and $\mathrm{n} \geq 6$ ), suggesting that the toxicity of uremic serum on zebrafish 
embryos may be mediated by protein molecule(s) (table 2). EDTA, an inhibitor of complement, diminished toxicity when added to uremic serum $(96 \pm 5 \%)$, compared to uremic serum alone $(28 \pm 20 \%)$, and yielded survival similar to normal serum ( $94 \pm 6 \%, \mathrm{p}<0.016$ and $\mathrm{n}$ $\geq 4$; table 3 ). To specifically test that complement may be mediating uremic toxicity, a monoclonal antibody to complement factor B was added to uremic serum [12]. Uremic serum with anti-factor B was significantly less toxic than uremic serum alone or uremic serum plus a nonspecific murine IgG (98 \pm 6 vs. $3 \pm 9$ and $1 \pm 4 \%$, respectively; $\mathrm{p}<0.016$ and $\mathrm{n} \geq 12$; table 4 ).

\section{Discussion}

Establishing links between individual retained solutes and uremic toxicity has been hindered by several factors, among them the lack of an animal model. Several epidemiologic studies have described a relationship between individual uremic solutes and mortality [5-7]. However, with very few exceptions, there is little compelling data linking a specific uremic toxin to its pathologic effect.

Solutes that are relatively poorly removed by hemodialysis include those that are protein bound or of large size. Such solutes are therefore especially elevated in the plasma of dialysis patients [4].

The zebrafish has previously been established as a useful model for the study of environmental and pharmacologic toxicity [10]. This study, however, represents the first attempt to use the zebrafish to model uremic toxicity. Zebrafish embryos exposed to uremic serum exhibited significantly more toxicity than those exposed to the serum of normal subjects. Fractionation experiments demonstrated that the toxicity was associated with solutes in the size fraction of $>50 \mathrm{kDa}$, implicating a molecule that is either large or protein bound.

Among the larger molecules likely to be toxic are those of the complement cascade. Given that strong possibility, we tested sequentially maneuvers known to interfere with the complement system. First, heating rendered the uremic serum innocuous. Next, EDTA, a nonspecific inhibitor of complement, abrogated the toxicity of uremic serum. mAb 1379 is a specific inhibitor of factor B, an essential component of the alternative complement pathway, and has been shown to inhibit complement activity in various animal models, as well as human serum [12]. Furthermore, it has been demonstrated to protect against the development of complement-mediated disease in mouse models of antiphospholipid antibody-induced fe-
Table 1. Percent survival in fractionated uremic serum, $<50$ and $>50 \mathrm{kDa}$, at $7 \mathrm{~h}$

\begin{tabular}{lc}
\hline Fractionated uremic serum & Percent survival \\
\hline$<50 \mathrm{kDa}$ & $83 \pm 11$ \\
$>50 \mathrm{kDa}$ & $7 \pm 17$ \\
\hline
\end{tabular}

$\mathrm{p}<0.05, \mathrm{n}=5$ ( $\mathrm{n}$ refers to the number of independent experimental observations, each evaluating the survival of approx. 10 embryos).

Table 2. Percent survival in control, uremic, and heated uremic serum at $7 \mathrm{~h}$

\begin{tabular}{lc}
\hline Serum at $7 \mathrm{~h}$ & Percent survival \\
\hline Control & $96 \pm 6$ \\
Uremic & $32 \pm 25$ \\
Heated uremic & $100 \pm 0$ \\
\hline
\end{tabular}

$\mathrm{p}<0.0167, \mathrm{n} \geq 6$ ( $\mathrm{n}$ refers to the number of independent experimental observations, each evaluating the survival of approx. 10 embryos).

Table 3. Percent survival in control, uremic, and uremic + EDTA serum at $7 \mathrm{~h}$

\begin{tabular}{ll}
\hline Serum at $7 \mathrm{~h}$ & Percent survival \\
\hline Control & $94 \pm 6$ \\
Uremic & $28 \pm 20$ \\
Uremic + EDTA & $96 \pm 5$ \\
\hline
\end{tabular}

$\mathrm{p}<0.0167, \mathrm{n} \geq 4$ ( $\mathrm{n}$ refers to the number of independent experimental observations, each evaluating the survival of approx. 10 embryos).

Table 4. Percent survival in uremic, uremic + anti-factor $\mathrm{B} A \mathrm{~b}$ (Ab 1379), and uremic + control Ab (clone 171) serum at $7 \mathrm{~h}$

\begin{tabular}{lc}
\hline Serum at $7 \mathrm{~h}$ & Percent survival \\
\hline Uremic & $3 \pm 9$ \\
Uremic + anti-factor B Ab & $98 \pm 6$ \\
Uremic + control Ab & $1 \pm 4$
\end{tabular}

$\mathrm{p}<0.0167, \mathrm{n} \geq 12$ ( $\mathrm{n}$ refers to the number of independent experimental observations, each evaluating the survival of approx. 10 embryos). 
tal loss [12]. This antibody completely largely abolished the toxicity of uremic serum, strongly suggesting that the demonstrated toxicity is complement dependent.

A large number of compounds have been identified as elevated in the serum of ESRD patients maintained on hemodialysis. These retained solutes are presumed to cause the uremic condition that persists in ESRD patients, even with adequate maintenance hemodialysis - what Depner [13] termed 'residual syndrome' characterized by decreased survival, end-organ damage, functional decline, and neurocognitive deficits, as well as multiple disparate metabolic derangements [14]. Vanholder and colleagues $[15,16]$ have compiled a list of known uremic solutes and described their potential toxic effects. A few studies have demonstrated epidemiologic links between individual retained solutes and mortality in ESRD patients. To date, little work has been done to demonstrate the pathologic mechanism of any specific retained solute, although recent studies have demonstrated the influence of several uremic toxins on endothelial function $[17,18]$.

The present study is the first to employ an animal model to link complement activity to uremic toxicity. Complement is a relatively well-described uremic solute. Factor D, a rate-limiting component of the alternative pathway of complement activation, has a molecular weight of $24 \mathrm{kDa}$, is filtered by the glomerulus, and catabolized by the proximal tubular epithelium $[19,20]$.

Clearance is reduced in human subjects with kidney disease, and plasma levels of factor D correlate well and inversely with glomerular filtration rate [21]. Other small components of the complement cascade such as C3a may also accumulate in uremia, but have not been explored in the same detail as factor D. We suspect that factor D probably in the company of other smaller element of the complement system or even unrelated compounds activate the larger elements of the pathway such as $\mathrm{C} 3$ in vivo and account for the residual toxicity residing above the molecular weight cutoff of $50 \mathrm{kDa}$. In addition, accumulation due to decreased clearance, complement activation, or even increased synthesis of some components may occur with uremia treated by dialysis. For example, exposure of blood to artificial surfaces within the hemodialysis membrane may stimulate the formation and activation of complement [22], although this may be ameliorated by more biocompatible dialyzers [23]. Furthermore, hemodialysis patients may have increased exposure to endotoxin, either from the dialysis procedure itself or due to reduced immune function, which may be a further stimulant of complement activation [24]. Complement has been identified in the intima of atherosclerotic plaques in both normal and uremic patients, and may contribute to the local inflammatory environment thought to be essential to the development of vascular disease [25-27].

The present results open several potential lines of inquiry in the treatment of ESRD. Since the advent of hemodialysis, therapy has focused almost exclusively on the clearance of urea. However, urea is relatively nontoxic and likely plays little role in uremic toxicity [28]. Moreover, many potential uremic toxins, some complement components among them, are poorly removed by urea-based dialysis prescriptions. Nevertheless, it must be acknowledged that conventional hemodialysis targeted at urea removal does dramatically reverse the severest symptoms of untreated uremia and can sustain life for years. The residual chronic disabilities that hemodialyzed patients sustain may be related to these poorly dialyzed solutes.

High-flux membranes designed to remove proteins in the size range of $\beta 2$-microglobulin $(13 \mathrm{kDa})$ have been in use for many years. However, the clearances are still rather modest when compared to the native kidney. Thus, though lower with high-flux membranes than with older types of dialyzers, serum levels of 'middle molecules' are still much higher than normal. In fact, while high-flux hemodialysis does remove factor $\mathrm{D}$, the effect is relatively modest compared to urea, or even $\beta 2$-microglobulin removal [29]. Moreover, there are numerous potential therapies that target complement activation and production, and may prove effective in the treatment of patients with ESRD.

In summary, uremic serum is toxic to zebrafish embryos though a complement-mediated pathway. Accumulation of complement components, their activation and/or increases in their synthesis may contribute to uremic toxicity.

\section{Acknowledgements}

T.H.H. was supported for these studies by a pilot and feasibility grant from the O'Brien Center and R21 NIH R21 DK77326.

References Janssen DJ, Spruit MA, Wouters EF, Schols
JM: Daily symptom burden in end-stage
chronic organ failure: a systematic review.
Palliat Med 2008;22:938-948.
2 US Renal Data System: USRDS 2010 Annual
Data Report: Atlas of End-Stage Renal Dis-
ease in the United States. Bethesda, National
Institutes of Health, National Institute of Dia-
betes and Digestive and Kidney Diseases,
2010.

Berman/Lectura/Thurman/Reinecke/Raff/ Melamed/Quan/Evans/Meyer/Hostetter 
3 Vanholder R, Baurmeister U, Brunet P, Cohen G, Glorieux G, Jankowski J, European Uremic Toxin Work Group: A bench to bedside view of uremic toxins. J Am Soc Nephrol 2008; 19:863-870.

-4 Vanholder R, De Smet R, Glorieux G, Argilés A, Baurmeister U, Brunet P, Clark W, Cohen G, De Deyn PP, Deppisch R, Descamps-Latscha B, Henle T, Jörres A, Lemke HD, Massy ZA, Passlick-Deetjen J, Rodriguez M, Stegmayr B, Stenvinkel P, Tetta C, Wanner C, Zidek W, European Uremic Toxin Work Group (EUTox): Review on uremic toxins: classification, concentration, and interindividual variability. Kidney Int 2003;63:1934-1943.

$\checkmark 5$ Meijers BK, Claes K, Bammens B, de Loor H, Viaene L, Verbeke K, Kuypers D, Vanrenterghem Y, Evenepoel P: p-Cresol and cardiovascular risk in mild-to-moderate kidney disease. Clin J Am Soc Nephrol 2010;5:1182-1189.

-6 Wu IW, Hsu KH, Hsu HJ, Lee CC, Sun CY, Tsai CJ, Wu MS: Serum free p-cresyl sulfate levels predict cardiovascular and all-cause mortality in elderly hemodialysis patients - a prospective cohort study. Nephrol Dial Transplant 2012;27:1169-1175.

-7 Barreto FC, Barreto DV, Liabeuf S, Meert N, Glorieux G, Temmar M, Choukroun G, Vanholder R, Massy ZA, European Uremic Toxin Work Group (EUTox): Serum indoxyl sulfate is associated with vascular disease and mortality in chronic kidney disease patients. Clin J Am Soc Nephrol 2009;4:15511558.

8 Rubinstein AL: Zebrafish assays for drug toxicity screening. Expert Opin Drug Metab Toxicol 2006;2:231-240.

-9 Hill AJ, Teraoka H, Heideman W, Peterson RE: Zebrafish as a model vertebrate for investigating chemical toxicity. Toxicol Sci 2005; 86:6-19.

10 Kari G, Rodeck U, Dicker AP: Zebrafish: an emerging model system for human disease and drug discovery. Clin Pharmacol Ther 2007;82:70-80.
11 Westerfield M: The Zebrafish Book: A Guide for the Laboratory Use of Zebrafish (Danio rerio), ed 3. Eugene, University of Oregon Press, 1995.

12 Thurman JM, Kraus DM, Girardi G, Hourcade D, Kang HJ, Royer PA, Mitchell LM, Giclas PC, Salmon J, Gilkeson G, Holers VM: A novel inhibitor of the alternative complement pathway prevents antiphospholipid antibody-induced pregnancy loss in mice. Mol Immunol 2005;42:87-97.

13 Depner TA: Uremic toxicity: urea and beyond. Semin Dial 2001;14:246-251.

14 Meyer TW, Hostetter TH: Uremia. N Engl J Med 2007;357:1316-1325.

15 Glorieux G, Vanholder R: New uremic toxins - which solutes should be removed? Contrib Nephrol. Basel, Karger, 2011, vol 168, pp 117-128.

16 De Smet R, Van Kaer J, Van Vlem B, De Cubber A, Brunet P, Lameire N, Vanholder R: Toxicity of free p-cresol: a prospective and cross-sectional analysis. Clin Chem 2003;49: 470-478.

17 Schepers E, Barreto DV, Liabeuf S, Glorieux G, Eloot S, Barreto FC, Massy Z, Vanholder R: Symmetric dimethylarginine as a proinflammatory agent in chronic kidney disease. Clin J Am Soc Nephrol 2011;6:2374-2383.

18 Schepers E, Glorieux G, Dou L, Cerini C, Gayrard N, Louvet L, Maugard C, Preus P, Rodriguez-Ortiz M, Argiles A, Brunet P, Cohen G, Jankowski J, Jankowski V, Massy Z, Rodriguez M, Vanholder R, European Uremic Toxin Work Group (EUTox): Guanidino compounds as cause of cardiovascular damage in chronic kidney disease: an in vitro evaluation. Blood Purif 2010;30:277-287.

19 Pascual M, Steiger G, Estreicher J, Macon K, Volanakis JE, Schifferli JA: Metabolism of complement factor $\mathrm{D}$ in renal failure. Kidney Int 1988;34:529-536.
20 Sanders PW, Volanakis JE, Rostand SG, Galla $\mathrm{JH}$ : Human complement protein D catabolism by the rat kidney. J Clin Invest 1986;77: 1299-1304.

21 Volanakis JE, Barnum SR, Giddens M, Galla $\mathrm{JH}$ : Renal filtration and catabolism of complement protein D. N Engl J Med 1985;312:395399.

22 Deppisch R, Schmitt V, Bommer J, Hänsch GM, Ritz E, Rauterberg EW: Fluid phase generation of terminal complement complex as a novel index of bioincompatibility. Kidney Int 1990;37:696-706.

23 Schaefer RM, Huber L, Gilge U, Bausewein K, Vienken J, Heidland A: Clinical evaluation of a new high-flux cellulose acetate membrane. Int J Artif Organs 1989;12:85-90.

24 Lonnemann G, Behme TC, Lenzner B, Floege J, Schulze M, Colton CK, Koch KM, Shaldon S: Permeability of dialyzer membranes to TNFa-inducing substances derived from water bacteria. Kidney Int 1992;42:61-68.

25 Deppisch RM, Beck W, Goehl H, Ritz E: Components as uremic toxins and their potential role as mediators of microinflammation. Kidney Int Suppl 2001;78:S271-S277.

26 Speidl WS, Kastl SP, Huber K, Wojta J: Complement in atherosclerosis: friend or foe? J Thromb Haemost 2011;9:428-440.

27 Malik TH, Cortini A, Carassiti D, Boyle JJ, Haskard DO, Botto M: The alternative pathway is critical for pathogenic complement activation in endotoxin- and diet-induced atherosclerosis in low-density lipoprotein receptor-deficient mice. Circulation 2010;122: 1948-1956.

28 Johnson WJ, Hagge WW, Wagoner RD, Dinapoli RP, Rosevear JW: Effects of urea loading in patients with far-advanced renal failure. Mayo Clin Proc 1972;47:21-29.

29 Ward RA, Schmidt B, Hullin J, Hillebrand GF, Samtleben W: A comparison of on-line hemodiafiltration and high-flux hemodialysis: a prospective clinical study. J Am Soc Nephrol 2000;11:2344-2350. 